\title{
KAJIAN HUBUNGAN RUANG DALAM PADA BANGUNAN GEREJA ST. MARIA FATIMA, SRAGEN, JAWA TENGAH
}

\author{
Sriwinarsih Maria Kirana \\ (Email:voila1078@yahoo.com ) \\ Desain Interior \\ Fakultas Seni Rupa dan Desain \\ Universitas Kristen Maranatha \\ Jl. Prof. Drg. Suria Sumantri 65, Bandung, Indonesia
}

\begin{abstract}
ABSTRAK
Sebuah objek bangunan adalah nyata, terukur, dan terlihat, yang terbangun karena ada bentuk (form), ide, dan ekspresi. Namun, dari sebuah teori diungkapkan bahwa bentuk (form) ini adalah sesuatu yang tertinggal setelah massa-nya tidak lagi melekat, tetapi tetap ada karena ekspresi manusianya, sehingga ada sebuah ruang yang tetap ada walaupun tidak dibatasi pembentuk ruang secara fisik. Melalui tulisan ini akan diperlihatkan bahwa objek bangunan yang nyata, terukur, dan terlihat itu terbentuk bukan hanya dari ruang yang dibatasi oleh bidang maupun container/pelingkup yang nyata, tetapi juga dari a space in between the cointainer bersifat nonfisik dan simbolis. Metode penelitian yang dilakukan adalah pengamatan pada objek studi dengan sebuah pendekatan teori ruang Lipps yang menyatakan bahwa perancangan sebuah bangunan adalah seni pembentukan ruang abstrak dan pengalaman ruang. Objek studi dalam penulisan ini adalah bangunan gereja St. Maria Fatima di Sragen, Jawa Tengah. Sebagai tempat berekspresi dalam peribadatan, sang perancang ingin menyampaikan pesan bagaimana hubungan manusia dangan Allah melalui hubungan ruang dalam pelingkup maupun di luar pelingkup. Melalui tulisan ini, diharapkan akan memperdalam wawasan perancang dalam merancang sebuah objek bangunan supaya tidak hanya memperhatikan yang sifatnya fisik, karena di situlah bukan hanya aktivitas manusianya, tetapi ekspresi manusia dinyatakan.
\end{abstract}

Kata Kunci: ruang abstrak; gereja; simbolis

\section{ABSTRACT}

A building object is real, measurable, and visible, which is built because there are forms, ideas, and expressions. However, from a theory it is revealed that this form is something that is left behind after its mass is no longer attached, but still exists because of its human expression, so that there is a space that still exists even though it is not confined to the physical forming of space. Through this paper it will be shown that the real, measurable, and visible building object are formed not only from the space constrained by the real field or container / scope, but also from a space in between the container which is nonphysical and symbolic. Observation of the object study with Lipps' space theory approach is the research method that is used. The object of study is the building of St.Maria Fatima church in Sragen, Central Java, a place of expression in worship, the designer wants to convey the message of how the human relationship with God through the relationship of space inside and outside the container. What is expected through this paper is to deepen the insight of designer in designing a building, as not only focus on the physical side. Not just human activity, but also human expression is needed to be expressed.

Keywords: abstract space; church; symbolic 


\section{PENDAHULUAN}

Sebuah objek material menurut A.M. Ampere (1775-1836), dibedakan menjadi dua yaitu secara kosmologis dan noologis. Secara kosmologis, objek itu nyata, terlihat, dapat diukur. Sementara secara noologis, objek itu tidak terukur, tidak nyata, tidak terlihat. Sebuah objek bangunan adalah sesuatu yang kosmologis dan real. Namun objek bangunan yang nyata, terukur, dan terlihat ini, terbangun karena adanya bentuk (form), ide, dan ekspresi. Dari sebuah teori, diungkapkan bahwa bentuk (form) ini adalah sesuatu yang tertinggal setelah massa-nya tidak lagi melekat. Tulisan ini bertujuan untuk memperlihatkan bahwa sebuah ruang yang nyata, terukur, dan terlihat itu terbentuk bukan hanya dari ruang yang dibatasi oleh bidang maupun container/pelingkup yang nyata, berada dalam sebuah bangunan, tetapi juga dari a space in between the cointainer, sebuah tempat diantara pelingkup yang dapat bersifat nonfisik dan simbolis. Ruang di luar banguanan dan di dalam bangunan meskipun dapat dibedakan, tetapi dapat saling berhubungan, sehingga dapat menjadi sebuah pertimbangan untuk merelasikannya dalam sebuah desain. Melalui tulisan ini, diharapkan akan memperdalam wawasan perancang dalam merancang sebuah objek bangunan supaya tidak hanya memperhatikan yang sifatnya fisik, karena di situlah bukan hanya aktivitas manusianya, tetapi ekspresi manusia dinyatakan.

\section{METODE PENELITIAN}

Bangunan yang dijadikan objek studi adalah Gereja Katolik St Maria Fatima di Sragen, Jawa Tengah. Bangunan gereja ini dirancang oleh Romo Mangunwijaya seorang arsitek sekaligus pemimpin rohani. Pemikiran sang perancang adalah menjebol model gereja-gereja dengan bangunan yang tertutup, bertembok masif, eksklusif serta tidak bersaudara dengan kanan-kiri, menjadikan aktivitas manusia untuk beribadah menjadi tidak tertutup oleh pelingkup ruang bersifat fisik Melalui medium yang bersifat abstrak, terbentuk ruang fisik karena ada hubungan antar manusia dan hubungan manusia dengan objek. Semangat lokalitas yang kuat dan kesederhanaan bentuk bangunan di tengah kota kecil namun sarat makna dari buah pikir seorang arsitek lokal, menjadi hal-hal menarik sebagai alasan dipilihnya bangunan gereja ini sebagai objek studi.

Selain melakukan pengamatan pada objek studi, dilakukan juga studi literatur dari teori yang berhubungan dengan ruang. Theodor Lipps (1839) menyampaikan suatu teori mengenai ruang: 
"Wujud (shape) dari objek adalah massa-nya, sedangkan bentuk (form) merupakan apa yang tertinggal setelah memindahkan massa-nya." Jadi menurutnya, perancangan sebuah bangunan merupakan seni pembentukan ruang abstrak dan pengalaman ruang. Dari bangunan gereja St Maria Fatima ini akan dilihat bagaimana hubungan teori Lipps dan konsep sang perancang (arsitek) tentang pembentukan ruang fisik dari ruang-ruang abstrak dan pengalaman ruang.

\section{PEMBAHASAN}

Pengertian "ruang" (space) sangatlah luas dan beragam. Ruang atau space dan berdasarkan terminologinya berasal dari istilah Latin yaitu spatium. Istilah space sendiri berarti suatu bentuk tiga demensi, permukaan luas yang menerus memanjang ke segala arah dan berisikan segala sesuatu: dengan berbagai cara dipikirkan sebagai sesuatu yang tak terbatasi. Atau juga dapat berarti berjarak, bidang yang luas, atau area di antara, di atas atau didalamnya (Webster's New World College Dictionary. NY: Macmillan. 1996:1284).

Sementara itu, secara umum ruang dibentuk oleh tiga elemen pembentuk ruang, yaitu bidang alas (the base plane), bidang dinding (the vertical space divider), bidang langit-langit (the overhead plane). Ketiga elemen tersebut tidak selalu bersifat nyata tetapi dapat bersifat simbolik. Tidak selamanya ruang adalah bersifat sesuatu yang obyektif atau nyata, tetapi merupakan sesuatu yang subyektif sebagai hasil pikiran dan perasaan manusia (Immanuel Kant, 1770). Selain ketiga unsur di atas, terdapat beberapa faktor lain yang turut mempengaruhi terbentuknya suatu ruang dan membentuk kualitas ruang ketika berhubungan dengan manusia.

Menurut Forrest Wilson dalam Struktur Esensi Arsitektur (1972), hubungan manusia dengan ruang yang paling penting adalah perasaan teritorial. Perasaan ini memenuhi kebutuhan dasar akan identitas diri, kenyamanan, dan rasa aman pada pribadi manusia.

Pengalaman manusia terhadap ruang, oleh Lefebvre (1991), dibagi ke dalam tiga konsep produksi ruang, yaitu: 
- Perseived Space: setiap ruang memiliki aspek persepsi yang dapat ditangkap oleh panca indera manusia. Aspek ini berkaitan dengan elemen material yang membentuk sebuah ruang.

- Conceived Space: ruang akan dapat dipersepsi setelah diterima dan dipahami oleh pikiran. Ketika ruang terbentuk melalui rangkaian elemen-elemen material, maka hal ini menjadi sebuah kegiatan ilmu pengetahuan.

- Lived Space: Dimensi ketiga dari produksi ruang adalah pengalaman serta praktek hidup manusia sehari-hari di dalam ruang. Pengalaman praktis manusia di dalam ruang tidak akan selesai melalui analisa teori, kadang-kadang hanya dapat dijelaskan melalui caracara artistik

Ruang pada umumnya dibagi menjadi dua bagian yang mendasar, yaitu: ruang luar dan ruang dalam. Masing-masing dari dua bagian tersebut mempunyai elemen-elemen pencipta arsitektur yang sama, yaitu: lantai, dinding dan atap. Ruang dalam pada umumnya dikatakan interior batasan pembentuk ruang yang sangat jelas, sedangkan ruang luar dapat bersifat meluas atau menyempit.

Yoshinobu Ashihara (1974) dalam buku Merancang Ruang Luar (terjemahan) menyatakan ruang luar ialah ruang yang terjadi dengan membatasi alam, dipisahkan dari alam dengan memberi frame, atau batasan tertentu. Ruang luar juga berarti sebagai lingkungan luar buatan manusia dengan maksud tertentu.

Prabawasari dan Suparman (1999) dalam bukunya Tata Ruang Luar 1 menyatakan ruang luar adalah:

- Ruang yang terjadi dengan membatasi alam hanya pada bidang alas dan dindingnya, sedangkan atapnya dapat dikatakan tidak terbatas.

- Sebagai lingkungan luar buatan manusia, yang mempunyai arti dan maksud tertentu dan sebagai bagian dari alam.

- Arsitektur tanpa atap, tetapi dibatasi oleh dua bidang: lantai dan dinding atau ruang yang terjadi dengan menggunakan dua elemen pembatas. Hal ini menyebabkan bahwa lantai dan dinding menjadi elemen penting di dalam merencanakan ruang luar. 
Kehadiran gereja Katolik di Indonesia dalam perkembangannya, melewati proses inkulturasi. Melalui proses ini, gereja tidak hanya dituntut untuk berkontribusi pada kebudayaan setempat, melainkan belajar dari budaya setempat dan memperkaya diri dengan nilai-nilai setempat. Semangat inkulturasi pun mempengaruhi arsitektur Gereja Katolik di Indonesia, bentuk-bentuk bangunan gereja pun semakin banyak yang bernafaskan kelokalan.

Selain fungsi liturgial, bangunan gereja juga berperan dalam mengekspresikan misi dan hakekat agama Katolik (McGuire dalam Joyce M.Laurens, 2013). Bangunan gereja harus mampu membentuk keterbukaan untuk menampung setiap orang, sehingga dapat menciptakan rasa kebersamaan, kesatuan, dan kerukunan serta membentuk komunitas.

Beberapa faktor kontekstual menguatkan dan mempengaruhi terbentuknya ikulturasi, sehingga menciptakan keanekaan bentuk arsitektur bangunan gereja Katolik yang menonjolkan lokalitas. Salah satu faktor tersebut adalah sosial-budaya.

Sosial-budaya, merupakan kekuatan non alami yang terbentuk karena perkembangan sosial budaya masyarakat, selalu berubah mengikuti perkembangan kondisi masyarakat dalam kehidupan sehari-hari. Pada lokasi dengan faktor sosial budaya yang masyarakatnya bersifat lebih homogen dan menganut budaya lokal yang kuat, proses inkulturasi berjalan lebih kuat dibandingkan dengan lokasi yang masyarakatnya lebih heterogen seperti di kota-kota besar.

Bangunan gereja St. Maria Fatima berada di sebuah lokasi yang bersatu dengan bangunan pendidikan dan area pastori. Pelingkup ruang/kontainer tidak dibiarkan masif membatasi antara ruang luar dan ruang dalam, sehingga menjadi selalu terbuka, langsung berhubungan dengan kehidupan sehari-hari. Ruang luar terbagi menjadi 2 yaitu, ruang luar mikro dan ruang luar makro (Markus Zahnd, 2009:22). Ruang luar mikro merupakan ruang-ruang antara massa bangunan dalam lingkungan, sementara ruang luar makro terbentuk dalam skala yang lebih besar, biasanya dalam tingkatan kota. Dengan demikian, yang dimaksud dengan ruang luar pada bangunan gereja ini adalah ruang luar mikro, karena berada di antara bangunanbangunan lain dalam satu kompleks pastoral (Gbr 1). 


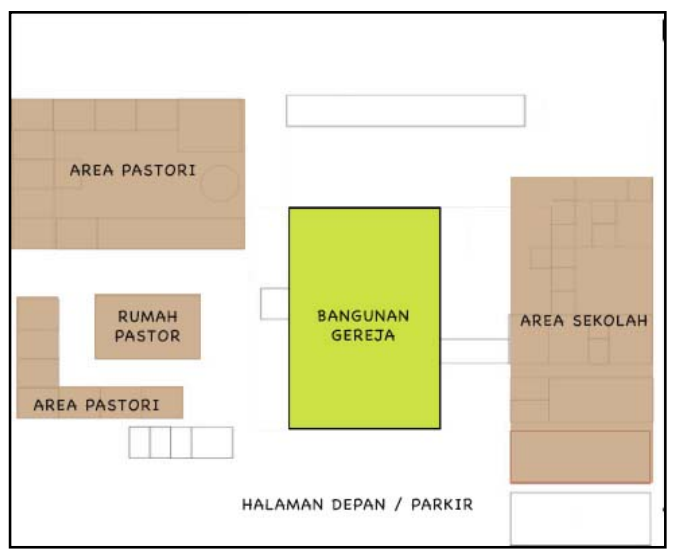

Gambar 1. Blok Plan Kompleks Gereja Sumber: dokumen pribadi

Bangunan Rumah Pastor yang dibangun tahun 1900-an awal, pada mulanya bukan berfungsi sebagai rumah pastor, melainkan rumah tinggal warga biasa. Ruang-ruang luar yang terbentuk lebih dahulu menjadi fokus pendekatan perancangan. Keterbukaan ruang menjadi pemersatu untuk fungsi-fungsi bangunan yang berbeda meskipun terdapat satu kesatuan nilai Katolik di dalamnya. Pendekatan pendopo sesuai dengan konteks bahwa sebagai ruang penerimaan, mewakili bangunan gereja yang selalu terbuka menerima setiap orang yang ingin datang.

Dibangun tahun 1965, bangunan gereja yang berada di sebuah kota kecil ini, menyerupai sebuah bangunan pendopo dalam kompleks rumah Jawa. Pendopo berada pada bagian rumah induk pada rumah tradisional Jawa, berfungsi sebagai tempat berkumpul orang banyak dan menerima tamu. Ruang ini bersifat terbuka, suasana yang tercermin adalah akrab, cocok dengan fungsinya sebagai tempat penerimaan. (Frick, 1997). Agar sesuai dengan konteks keberadaan bangunan yang ada di wilayah Jawa Tengah, pendopo dapat mewakili bentuk bangunan ciri khas setempat .

Dalam wacana arsitektur Indonesia, Romo Mangun dikenal sebagai seorang arsitek dan perencana dengan pemikiran multiperspektif dikarenakan latar belakang pendidikan dan pengalaman yang multidisiplin. Kekayaan wacana pengetahuan dan pengalaman beliau turut mewarnai artefak arsitektur yang dihasilkan. Perwujudan sebuah artefak arsitektur melalui sebuah rangkaian proses panjang filosofi, proses kreatif, pelaksanaan hingga komunikasi yang dilakukan menyingkapkan dua sisi sekaligus, yaitu sisi teknis yang mekanis dan sisi teknis yang manusiawi. 
Bentuk bangunan gereja yang menyerupai tipologi pendopo rumah Jawa ini menjadi sebuah bukti inkulturasi dinyatakan, sesuai dengan misi kehadiran gereja Katolik. Konsep keterbukaan pendopo bagi Orang Jawa tidak sepenuhnya terbuka dalam arti sebenarnya, melainkan memberikan suatu efek psikologis. Orang diajak merasakan suatu efek psikologis dengan melihat pendopo yang terbuka dan terbentang luas tanpa penghalang, sehingga membawa manusia untuk berhitung/menimbang-nimbang akan suatu kepantasan untuk berada di tengah tanpa adanya pemilik rumah. Hal ini termanifestasikan dalam suatu sikap seperti sungkan untuk bertingkah seenaknya di dalam pendopo. Keterbukaan pendopo memberikan pengalaman yang berbeda yang dirasakan seakan-akan ada sesuatu yang menuntun untuk bersikap sebaliknya. Memunculkan sikap canggung, sehingga kebebasan yang terjadi sangatlah mengikat.

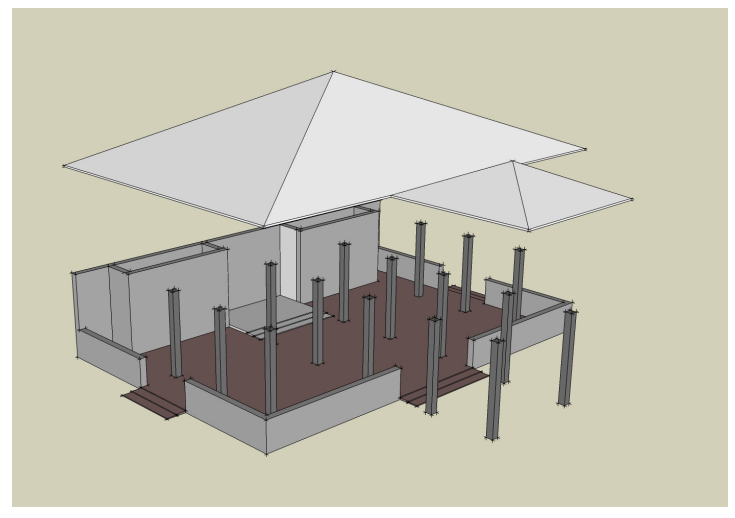

Gambar 2. Sketsa Layout 3 Dimensi Bangunan Gereja Sumber: dokumentasi pribadi

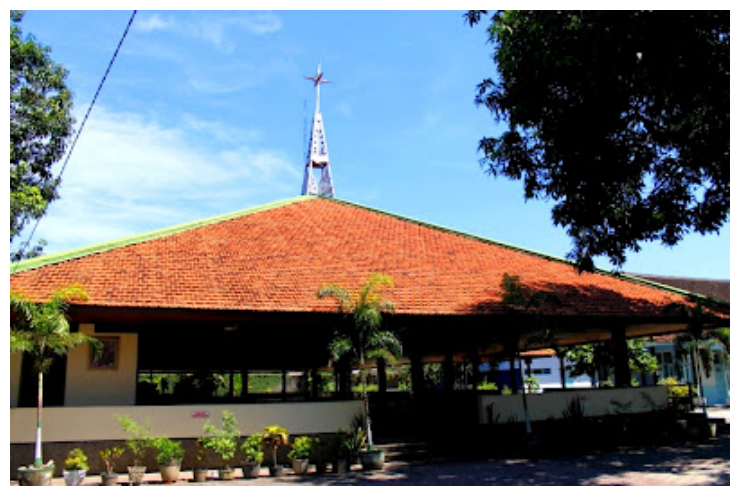

Gambar 3. Bentuk Bangunan Gereja Sumber: laman facebook Gereja Santa Maria Fatima, Sragen, Jawa Tengah 
Dengan keterbukaan yang ada, seperti yang terlihat pada Gambar 3, hubungan dengan ruang luar membentuk ekspresi dari furniture dalam ruang ibadah. Salah satunya adalah bangkubangku panjang tanpa sandaran seolah-olah memaksa jemaat bersikap duduk tegak dalam mengikuti rangkaian liturgi ibadah (Gbr 4). Duduk tegak dengan sungguh-sungguh menjadi cerminan sikap ibadah yang juga sungguh-sungguh. Hal ini dapat menjadi sebuah citra yang baik bagi orang-orang yang melihat dari luar bangunan gereja. Relasi dengan ruang luar membentuk suasana yang disadari atau tidak, mempengaruhi sikap dalam menjalankan aktivitas ibadat umat.

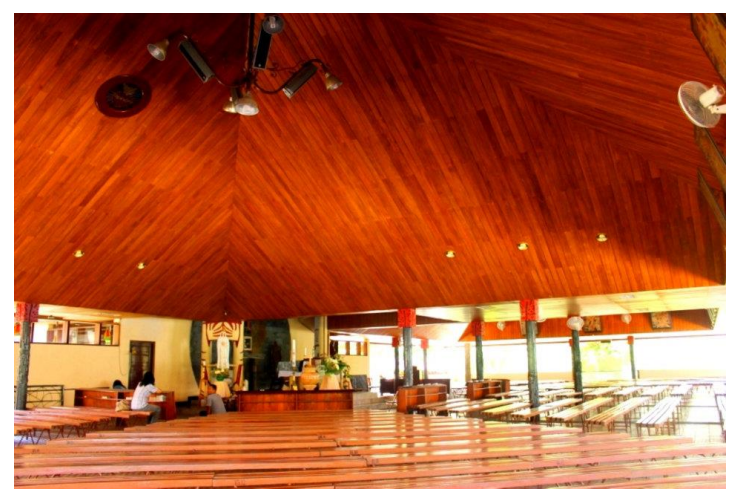

Gambar 4. Bangku Panjang Dalam Ruang Ibadah Sumber: laman facebook Gereja Santa Maria Fatima, Sragen, Jawa Tengah

Humanisme arsitektur adalah prioritas Romo Mangun dalam merancang bangunan. Bagaimana umat dapat berjumpa dengan Sang Penciptanya yang tidak hanya dijumpai dalam sebuah bangunan tertutup tetapi juga dijumpai dalam kehidupan sehari-hari. Dengan demikian, umat menjadi tidak canggung dan merasa asing dengan Penciptanya. Menurut Romo Mangun "Allah bukanlah Allah yang jauh dan menakutkan atau angker, sebagaimana ditampakkan dalam model bangunan gedung gereja yang "keramat" atau "angker". Tuhan adalah Allah yang dekat dengan kita, yang omong-omongan dengan kita dan ingin memberikan hidup-Nya dengan kita." Pelingkup ruang yang tidak masif ini menjadikan adanya hubungan antara ruang dalam dan ruang luar bangunan gereja, juga mengakibatkan adanya ruang antara ruang dalam dan ruang luar sebagai ekspresi bahwa di dalam dan di luar gereja itu sebenarnya tidak terpisahkan Aktivitas manusia dalam ruang yang berhubungan satu dengan lain, juga berhubungan dengan Tuhan dalam ekspresi peribadatan. Aktivitas peribadatan sesuai Liturgi Iman Katolik meliputi gerak duduk, berdiri, benyanyi, membaca, mendengarkan, berdoa, memberi persembahan, menerima hosti adalah aktivitas yang memerlukan ruang. Disinilah manusia mengalami sebuah 
ruang. Ekspresi gerak atau aktivitas manusia inilah yang dibatasi oleh objek material terukur, terlihat, dan nyata.

Pada bangunan gereja ini, elemen ruang dalam berupa ceiling atau plafond yang rendah, tidak seperti pada gereja umumnya (Gbr 5). Tanpa mengurangi maksud untuk menyadarkan skala manusia di hadapan Penciptanya melalui plafond yang rendah, sang perancang yang dikenal sangat efisien menggunakan material ini memanfaatkan sirkulasi udara yang sangat mudah masuk dan keluar melalui bukaan-bukaan di sekeliling bangunan. Ruang vertikal yang biasanya dimaksudkan untuk menyadarkan keberadaan manusia di hadapan Sang Pencipta, mengaplikasikan pemikiran teologis lain bahwa Allah adalah Allah Sang Pencipta yang dekat dengan ciptaan-Nya, yang omong-omongan dengan manusia, dan yang ingin memberikan hidup-Nya dengan kita. Sementara ruang vertikal yang sering dimanfaatkan untuk penghawaan dalam ruang, telah terakomodir melalui bukaan pada sisi-sisi bangunan. Sirkulasi udara yang terus bergerak karena bukaan-bukaan besar tersebut, sesuai pula dengan konteks alam (nature) tempat bangunan ini berdiri. Kota Sragen termasuk kota dengan suhu tinggi sehingga udara cukup panas. Melalui hubungan dengan ruang luar, kenyamanan jemaat ketika beribadah ataupun ketika melakukan aktivitas lainnya, tetap terjaga melalui aliran sirkulasi udara yang sangat baik. Ruang luar yang tidak dibatasi sekat akan mengalirkan udara dengan bebas.

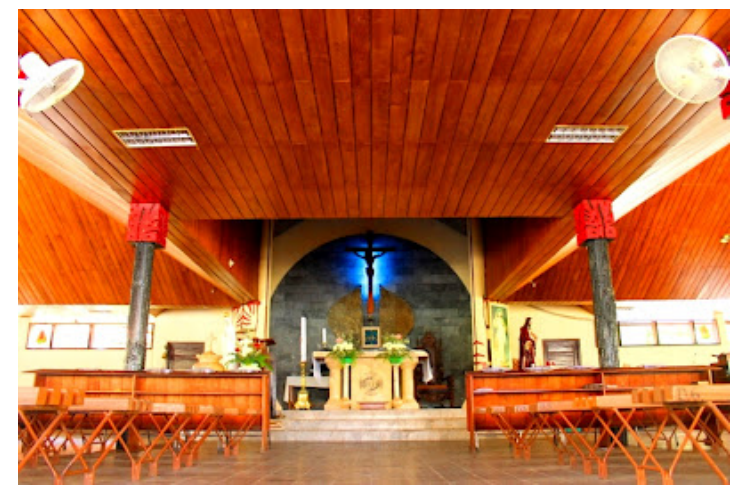

Gambar 5. Plafond Bangunan Gereja yang Tidak Terlalu Tinggi Sumber: laman facebook Gereja Santa Maria Fatima, Sragen, Jawa Tengah

Keterbukaan bangunan tanpa pintu masuk sebagai penyekat ruang mempertegas lagi makna hubungan antara ruang yang didalam bangunan dan di luarnya, tidak perlu dipisahkan. 
Keterbukaaan ke beberapa penjuru mata angin, mempermudah untuk masuk ke dalam bangunan gereja melalui berbagai sisi atau arah, karena di sekeliling bangunan terdapat bangunan dengan fungsi lain, sehingga siapa saja yang menuju bangunan gereja dari bangunan sekitarnya dapat mudah masuk (Gbr 6, 7, 8).

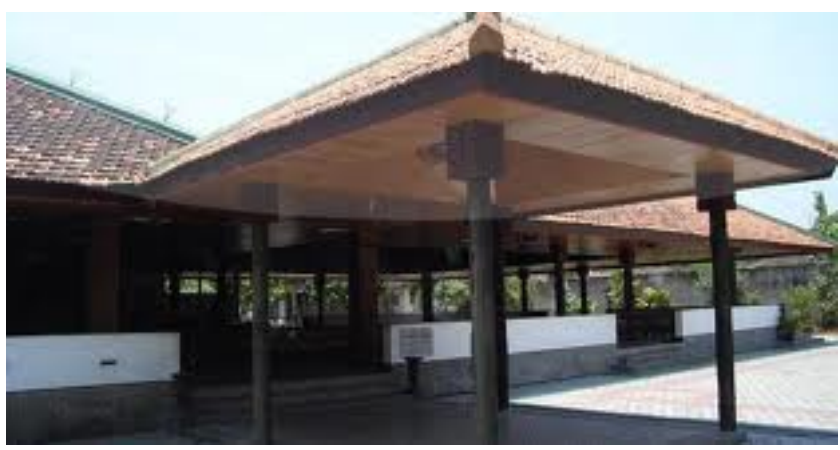

Gambar 6. Bukaan Utama dan Bukaan Lain di Sebelahnya Untuk Masuk ke Ruang Dalam Bangunan Gereja Sumber: laman facebook Gereja Santa Maria Fatima, Sragen, Jawa Tengah

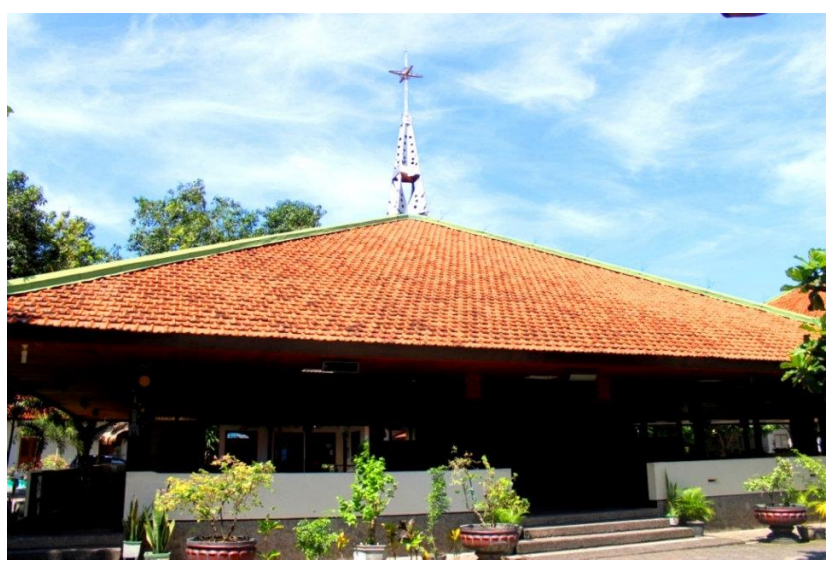

Gambar 7. Bukaan Pada Sisi Lain Untuk Masuk ke Dalam Bangunan Gereja Sumber: Iaman facebook Gereja Santa Maria Fatima, Sragen, Jawa Tengah 


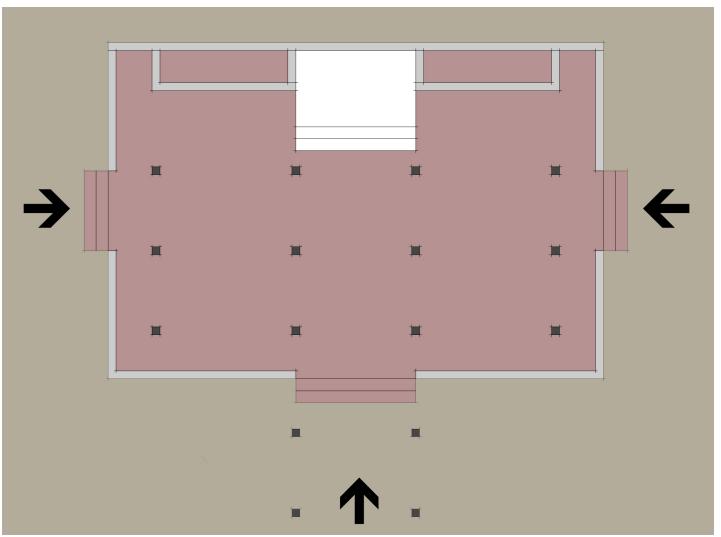

Gambar 8. Keterbukaan ke beberapa penjuru mata angina mempermudah untuk masuk ke dalam. Sumber: dokumentasi pribadi

Spasial merupakan salah satu cara untuk mengintrepretasikan materi. Pembatas-pembatas fisik yang kemudian akan membentuk ruangan menunjuk pada suatu aktivitas atau ekspresi yang perlu dibatasi ataupun tidak Jika melihat kembali pada dinding-dinding pembatas bangunan gereja Santa Maria Fatima yang tidak penuh (dibiarkan tidak masif), ekspresi dari ruang dalam akan terhubung dengan ruang luar, begitupun ekspresi dari ruang luar akan terhubung dengan ruang dalam bangunan gereja ini.

\section{PENUTUP}

Teori Lipps tentang wujud (shape) dari objek adalah massa-nya dan bentuk (form) merupakan apa yang tertinggal setelah memindahkan massa-nya dalam bangunan gereja St Maria Fatima ini terlihat dari konsep Romo Mangun sebagai sang arsitek melalui tempat manusia berekspresi dalam ibadahnya menjadi sebuah seni pembentukan ruang abstrak.

Pengamatan lebih jauh terhadap kegiatan manusia yang akan diwadahi dalam sebuah bangunan diperlukan untuk menangkap hubungan dalam ruang yang ingin ditampilkan pada sebuah bangunan. Dalam hal ini, pada sebuah bangunan gereja, salah satu pengamatan yang penting dilakukan adalah kehidupan sehari-hari manusia yang terus berhubungan dengan Allah dan sesama manusia sebagai bentuk ibadah., karena Allah Sang Pencipta tidak hanya dijumpai dalam sebuah bangunan tertutup tetapi juga dijumpai dalam kehidupan sehari-hari. 
Merancang bangunan merupakan seni pembentukan ruang abstrak dan pengalaman ruang terwujud dari bentuk serta makna bangunan yang mewakili ekspresi kegiatan manusia di dalamnya.

\section{DAFTAR PUSTAKA}

Ashihara, Yoshinobu. (1983). Exterior Design in Architecture, Terjemahan Gunadi, Sugeng, Surabaya: PT Dian Surya.

Lindstrom, M. (2005). Brand sense: Sensory Secrets Between Behind The Stuff We Buy. New York: Free Press.

Le Vebre, Henry (1991). The Production of Space. Basil Blackwell, inc.

Surasetja, Drs. R. Irawan, MT. (2007). Fungsi, Ruang, dan Ekspresi Dalam Arsitektur. Bahan Ajar: TA 110 - Pengantar Arsitektur Van de Ven, Cornelis (1991). Ruang Dalam Arsitektur, Jakarta: PT Gramedia Pustaka Utama. Y.B Mangunwijaya (2009). Wastu Citra: Pengantar ke Ilmu Budaya Bentuk Arsitektur Sendi-sendi Filsafatnya Beserta Contoh-contoh Praktis, Jakarta: PT Gramedia Pustaka Utama.

Zahnd, Markus (2009). Pendekatan Dalam Perancangan Arsitektur, Yogjakarta: Kanisius.

Wilson, Forrest. (1972). Structure Essence of Architecture. UK: Littlehampton Book Services Ltd (1996). Webster's New World College Dictionary. NY: Macmillan.

Prabawasari, Veronika Widi dan Suparman, Agus (1999). Diktat Kuliah Tata Ruang Luar 01. Jakarta: Gunadarma

Setiawan, Andi (2015). Produksi Ruang Sosial Sebagai Konsep Pengembangan Ruang Kota. Jurnal Haluan Sastra Budaya, Vol. 33, No. 66 